\title{
Development of Dribbling and Shooting Exercise Models in Futsal Sports (Development Study of POK Futsal Achievement Training in Sebelas Maret University)
}

\author{
Argya Setya Wimala; Muchsin Doewes; M. Furqon Hidayatullah \\ Postgraduate Sport Science Program, Universitas Sebelas Maret, Surakarta, Indonesia
}

http://dx.doi.org/10.18415/ijmmu.v6i1.619

\begin{abstract}
The purpose of this study was to develop a good dribbling and shooting exercise model and carry out the trial of the development product. The research method used in this study is a research and development method. The first step that was carried out was a needs analysis using the free guided interview method to find out the problems that existed in the development of POK UNS futsal achievements related to dribbling and shooting exercises. From the results of the interview, it is known that the students' dribbling and shooting abilities are still not good and there is no dribbling and shooting training program based on theoretical studies. From these results, the following topics can be formulated: (1) The general theory of futsal. (2) The theory of basic futsal techniques. (3) the general theory of dribbling and shooting exercises. (4) Dribbling and futsal shooting. Furthermore, the evaluation of product development in the dribbling and shooting training model that has been prepared to academic experts and trainers is obtained so that the final average score is $79.33 \%$ which indicates that the product design for the development of dribbling and shooting training models for students who have developed futsal achievements can be tested on the stage of small group trials and large group trials. The small group test results with 15 subjects were $82.83 \%$. The trial of a large group with a subject of 30 people with a result of $83.92 \%$. From the results of product testing, the product effectiveness test was then carried out to compare the increase in dribbling and shooting capabilities that were trained with the training models that had been made with conventional training models that were commonly done before. The results of the effectiveness test for dribbling using the new exercise model showed an average increase of 3.06 seconds, while those using the conventional training model showed an average increase of 0.15 seconds. Shooting using the new exercise model showed an average increase of 7.24 while those using conventional training models showed an average increase of 0.56 .
\end{abstract}

Keywords: Dribbling Training Model; Shooting Practice Model; Futsal

\section{Introduction}

Futsal (futbol sala in Spanish means indoor soccer) is a soccer game performed indoors. The game itself is carried out by five players per team, in contrast to conventional football which has eleven players per team. The size of the field and the size of the ball are smaller than the size used in soccer. In the last few years, the development of futsal is very widespread in Indonesia, and its development is very rapid in all circles of society. The size of the field and the size of the ball that are smaller than the size 
used in soccer, cause the land used is not wide. With smaller field sizes and fewer players, futsal games tend to be more dynamic.

The performance of the futsal game is very much supported by the skills possessed by the players. The more skilled the player is in mastering the game, the futsal game will become increasingly interesting and challenging. In futsal games, one of these skills is related to skills in mastering mature ball. Therefore, it requires strength, stamina, acceleration, and agile and fast foot movements. Basically, the basic futsal technique is a simple technique or movement, meaning that this technique is easy to do and can be learned through the training process. In basic techniques, there are several components of the movement or technique of playing futsal including dribbling and shooting which will be the variables in this study. Futsal achievement development in the POK department, Sebelas Maret University Surakarta is an achievement coaching for sports students with special interests and talents in futsal sports. Futsal achievement development students are projected to be able to become players at the university level, amateur teams, and even expected to become players in professional futsal teams. Therefore, from the beginning, these students must be provided with basic or relevant techniques in their training. It is hoped that when they have started plunging into the team, they have mastered the basic techniques well, especially dribbling and shooting.

Based on the results of interviews with the POK UNS Futsal coach, explained that the trainers did not have training programs and models to practice basic dribbling and shooting techniques. In providing dribbling and shooting exercises, the exercises given are only spontaneous according to the coach's wishes when training and only follow in accordance with what the trainer can do when training the trainer. Whereas from the observations of researchers in the field, athletes are still not good at doing basic techniques, especially dribbling and shooting techniques, and the training provided by the trainer is less varied. Dribbling and shooting exercises have indeed been given but there are still many athletes who have not been able to do dribbling and shooting techniques properly. Looking at the basic techniques of dribbling and shooting is very important, researchers are encouraged to research and develop a product in the form of a representative dribbling and shooting training model.

\section{Methodology}

This study uses a research development method because it is in accordance with the problems found in the preliminary study so that to solve the gap between expectations and reality, development research is suitable for this. The development model used by researchers is a procedural development model. This study uses Borg and Gall procedural development methods. From the ten steps of development proposed by Borg and Gall, there are several stages which are partially modified by researchers, with consideration of time, effort, and limited costs to produce products for dribbling and shooting training models to improve the ability of dribbling and shooting techniques in futsal for students. POK UNS Futsal. To find out the increase in the results of the application of product development, the researchers conducted experiments on product training models to improve the dribbling and shooting skills of students in the POK UNS Futsal Achievement Development. Data collected in this study include initial condition data, futsal expert assessment data, group trial data, and data on product development effectiveness test results. The type of research data for the development of training models for dribbling techniques and shooting in futsal is qualitative and quantitative data. Qualitative data includes observations from researchers, interviews with futsal coaches in preliminary studies, input from futsal experts, field notes during product experiments. Quantitative data includes data from expert evaluation questionnaires, data from athlete questionnaires during small group tests and large group tests, data from the results of the pre-test and post-test. 


\section{Result and Discussion}

Table1.Interview test results and product trials

\begin{tabular}{|c|c|c|}
\hline No & Component & Findings \\
\hline \multirow[t]{3}{*}{1} & Introduction Stage & \\
\hline & $\begin{array}{l}\text { Interview with futsal coach in Surakarta city } \\
\text { about dribbling and shooting skills, }(n=2) \\
\text { with } 5 \text { questions. }\end{array}$ & $\begin{array}{l}\text { The dribbling ability and shooting of futsal players } \\
\text { fostering futsal achievements in POK UNS are not } \\
\text { good and there is no dribbling and shooting training } \\
\text { program for students of POK UNS futsal } \\
\text { achievement. }\end{array}$ \\
\hline & $\begin{array}{l}\text { Observation of the exercise in POK UNS futsal } \\
\text { achievement training }\end{array}$ & $\begin{array}{l}\text { The lack of mastery of techniques in students } \\
\text { fostering POK UNS futsal achievements, this can be } \\
\text { seen when doing games for example when } \\
\text { dribbling, legs with the ball too far so that the } \\
\text { opponent is easily captured and when kicking the } \\
\text { ball, often not on target. }\end{array}$ \\
\hline \multirow[t]{5}{*}{2} & Trial Phase & \\
\hline & $\begin{array}{l}\text { a. Results of evaluating futsal experts }(n=3) \\
\text { with the number of instruments as many as } 10 \\
\text { questions. }\end{array}$ & $\begin{array}{l}\text { a. From the results of the evaluation of the } \\
\text { three futsal experts, a percentage of } \\
79.33 \% \text { was obtained, so the exercise } \\
\text { model could be tested. }\end{array}$ \\
\hline & & $\begin{array}{l}\text { b. From the input of futsal experts, the } \\
\text { design of the training model must be } \\
\text { tailored to the needs of the players, the } \\
\text { program design must be adapted to the } \\
\text { theory of practice. }\end{array}$ \\
\hline & $\begin{array}{l}\text { b. Small group trials }(n=15) \text { with the number } \\
\text { of instruments were } 8 \text { questions. }\end{array}$ & $\begin{array}{l}\text { From the results of the small group trial, the } \\
\text { percentage was } 82.83 \% \text {, so the training model could } \\
\text { be continued to the large group test stage. }\end{array}$ \\
\hline & $\begin{array}{l}\text { c. The trial of large groups }(n=30) \text { with the } \\
\text { number of instruments as many as } 8 \text { questions. }\end{array}$ & $\begin{array}{l}\text { From the results of a large group trial, the } \\
\text { percentage of } 83.92 \% \text { was obtained. }\end{array}$ \\
\hline
\end{tabular}

Based on the results of the interview tests conducted, it is known that there is no standard training model used in training, the ability of players is still much less visible from how to play while in the field. From the results of the survey in the field, then the preparation of training models was carried out and expert evaluations were carried out in relation to the exercise model made. From the results of the evaluation of the three futsal experts, a percentage of $79.33 \%$ was obtained, so the exercise model could be tested. From the input of futsal experts, the design of the training model must be tailored to the needs of students, the program design must be adjusted to the theory of practice.

Then a small group trial was conducted with a subject of 15 people. From the results of a small group trial using a questionnaire to find out which exercise models are made easy to understand and implement or not, a percentage of $82.83 \%$ is obtained so that the research can proceed to large group trials. In a large group trial with the number of subjects, 30 people obtained a percentage of $83.92 \%$.

That way the research continues to the effectiveness test phase to find out how effective these training models can be used to improve the ability of the players. The product effectiveness test in the research development of dribbling and shooting training models aims to see the difference in the influence of dribbling skills and shooting of futsal players in POK UNS Futsal Achievement Development among groups given dribbling and shooting training programs from development results and groups given conventional training. The group given the dribbling and shooting training program from the development results is called the bound group, while the group given the conventional training is called the control group. The effectiveness test of this product uses a quasi-experimental design. 
Table 2. Recapitulation of data on dribbling results in the bound and control groups pre-test and post-test

\begin{tabular}{|c|c|c|c|c|}
\hline \multirow{3}{*}{ Data Description } & \multicolumn{4}{|c|}{ Dribbling ability } \\
\hline & \multicolumn{2}{|l|}{ Bound } & \multicolumn{2}{|l|}{ Control } \\
\hline & Pre-test & Post- test & Pre-test & Post- test \\
\hline Range & $23,57-15,67$ & $18,95-14,04$ & $21,83-16,21$ & $21,54-16,34$ \\
\hline Amount of difference & 76,54 & & 3,75 & \\
\hline Average different & 3,06 & & 0,15 & \\
\hline $\begin{array}{l}\text { Standard deviation is } \\
\text { different }\end{array}$ & 0,71 & & 0,44 & \\
\hline $\mathrm{T}$ count & 21,63 & & 1,71 & \\
\hline T table & 2,06 & & 2,06 & \\
\hline
\end{tabular}

From the results of the pre-test and post-test, the dribbling ability in the bound group obtained a range of 23.57 - 15.67 for the pre-test and 18.95 - 14.04 for the post-test. The amount of difference is 76.54 with a difference in the average of 3.06 and a standard deviation of difference of 0.71 so that $t$ count is 21.63. From the results of the pre-test and post-test, the dribbling ability in the control group obtained a range of $21.83-16.21$ for the pre-test and $21.54-16.34$ for the post-test. The amount of difference is 3.75 with a difference in the average of 0.15 and a standard deviation of difference of 0.44 so that there is a count of 1.71 .

Table 3. Summary of data normality test results

\begin{tabular}{llllllll}
\hline Kelompok & Test & $\mathbf{n}$ & Average & $\begin{array}{l}\text { Standard } \\
\text { deviation }\end{array}$ & $\mathbf{L}_{\text {count }}$ & $\mathbf{L}_{\text {table }}$ & Conclusion \\
\hline Bound & Pre-test & 25 & 18,973 & 1,915 & 0,102 & 0,173 & Normal \\
Bound & Post-test & 25 & 15,911 & 1,361 & 0,135 & 0,173 & Normal \\
Control & Pre-test & 25 & 19,174 & 1,416 & 0,084 & 0,173 & Normal \\
Control & Post-test & 25 & 19,024 & 1,359 & 0,088 & 0,173 & Normal \\
\hline
\end{tabular}

From the results of the normality test conducted in the pre-test bound group, the calculated $\mathrm{L}$ count is 0.102 . With $\mathrm{n}=25$ and the real level of 0.05 , the $\mathrm{L}$ table count is 0.173 . It turns out that the calculated $\mathrm{L}$ count of 0.102 is smaller than the $\mathrm{L}$ table count of 0.173 , which means that the dribbling data on the bound group pre-test is normal. From the results of the normality test performed on the post-test bound group, the calculated $\mathrm{L}$ count was 0.135 . With $\mathrm{n}=25$ and the real level of 0.05 , the $\mathrm{L}$ table count is 0.173 . It turns out that the calculated $\mathrm{L}$ count of 0.135 is smaller than the $\mathrm{L}$ table count of 0.173 , which means that the dribbling data on the bound post-test group is normal.

From the results of the normality test conducted in the pre-test control group, the calculated $\mathrm{L}$ count was 0.084 . With $n=25$ and the real level of 0.05 , the $\mathrm{L}$ table count is 0.173 . It turns out that the calculated L count is 0.084 smaller than the $\mathrm{L}$ table count of 0.173 , this means that the data dribbling in 
the pre-test control group is normal. From the results of the normality test conducted in the post-test control group, the calculated $\mathrm{L}$ count was 0.088 . With $\mathrm{n}=25$ and the real level of 0.05 , the $\mathrm{L}$ table count is 0.173 . It turns out that the calculated $\mathrm{L}$ count is 0.088 smaller than the $\mathrm{L}$ table count of 0.173 , this means that the dribbling data in the post-test control group is normal.

Table 4. Summary of test results for homogeneity of the population variance

\begin{tabular}{lllllll}
\hline Group & $\mathbf{N}$ & $\begin{array}{l}\text { Standard } \\
\text { deviation }\end{array}$ & Variant & $\mathbf{F}_{\text {count }}$ & $\mathbf{F}_{\text {table }}$ & Conclusion \\
\hline Bound & 25 & 1,915 & 3,666 & & & \\
Control & 25 & 1,416 & 2,004 & 1,83 & 1,98 & Homogen \\
\hline
\end{tabular}

From the calculation of dribbling results in the bound and control groups, the calculated $\mathrm{F}$ count of 1.83 is obtained. With a numerical degree of freedom (DK) of 24 and the denominator's freedom (DK) of 24 and a real level $(\alpha)$ of 0.05 , the F table of 1.98 is obtained. It turns out that the calculated F count of 1.83 is smaller than the table F count of 1.98. This shows that the dribbling data in the bound and control groups are homogeneous.

Table 5. Data from the dribbling pre-test and post-test results

\begin{tabular}{llllllll}
\hline Group & $\sum$ Pre-Test & $\sum$ Post-Test & $\begin{array}{l}\sum_{\text {difference }} \\
\text { difference }\end{array}$ & $\mathbf{t}_{\text {count }}$ & $\mathbf{t}_{\text {table }}$ & Conclusion \\
\hline Bound & 474,32 & 397,78 & 76,54 & 3,06 & 21,63 & 2,06 & significant \\
\multirow{2}{*}{ Control } & 479,36 & 475,61 & 3,75 & 0,15 & 1,71 & 2,06 & Not significant \\
\hline
\end{tabular}

From the results of t-test calculations on the bound group, the count of $t$ count is 21.63 . By using the real level $(\alpha)$ of 0.05 and the degree of freedom (DK) of 24, the t table count obtained is 2.06. It turns out that the count of the $t$ count of 21.63 is greater than the count of the t table of 2.06, so there are significant differences between the results of the pre-test and post-test dribbling. This means that there is significantly a product influence on the development of a dribbling training model to improve the skills of futsal players in POK UNS Futsal Achievement Development. With the product development of the dribbling training model, empirically demonstrated by the increase in dribbling speed from the pre-test to post-test by 3.06 seconds.

From the results of t-test calculations in the control group, the count of $t$ count is 1.71 . By using the real level $(\alpha)$ of 0.05 and the degree of freedom (DK) of 24, the t table count obtained is 2.06. It turns out that the count of the $t$ count of 1.71 is greater than the count of t table of 2.06, so there is no significant difference between the results of the pre-test and post-test dribbling. This means that there is no influence of conventional models of dribbling training on futsal players. POK UNS Futsal Achievement Development. With the conventional model of dribbling exercises, empirically is shown by the very small increase in dribbling speed from the pre-test to post-test which is 0.15 seconds. 
Table 6. Recapitulation of shooting data on the bound and control groups pre-test and post-test

\begin{tabular}{|c|c|c|c|c|}
\hline \multirow{3}{*}{ Data Description } & \multicolumn{4}{|c|}{ Shooting Ability } \\
\hline & \multicolumn{2}{|l|}{ Bound } & \multicolumn{2}{|l|}{ Control } \\
\hline & Pre-test & Post- test & Pre-test & Post- test \\
\hline Range & $21-40$ & $29-46$ & $20-38$ & $20-39$ \\
\hline Amount of difference & 181 & & 14 & \\
\hline Average different & 7,24 & & 0,56 & \\
\hline $\begin{array}{l}\text { Standard deviation is } \\
\text { different }\end{array}$ & 1,96 & & 1,56 & \\
\hline $\mathrm{T}$ count & $-18,43$ & & $-1,80$ & \\
\hline $\mathrm{T}$ table & 2,06 & & 2,06 & \\
\hline
\end{tabular}

From the results of the pre-test and post-test shooting abilities in the bound group were obtained between 21 - 40 for the pre-test and 29 - 46 for the post-test. The number of difference is 181 with an average difference of 7.24 and a standard deviation of difference of 1.96 so that the calculated $t$ is -18.43 . From the results of the pre-test and post-test, the shooting ability in the control group obtained a range of 20-38 for the pre-test and 20-39 for the post-test. The amount of difference is 14 with an average difference of 0.56 and a standard deviation of difference of 1.56 so that the calculated $t$ is- 1.80 .

Table 7. Summary of data normality test results

\begin{tabular}{llllllll}
\hline Group & Test & $\mathbf{n}$ & Average & $\begin{array}{l}\text { standard } \\
\text { deviation }\end{array}$ & $\mathbf{L}_{\text {count }}$ & $\mathbf{L}_{\text {table }}$ & Conclusion \\
\hline Bound & Pre-test & 25 & 30,800 & 4,941 & 0,125 & 0,173 & Normal \\
Bound & Post-test & 25 & 38,040 & 4,383 & 0,155 & 0,173 & Normal \\
Control & Pre-test & 25 & 29,840 & 4,497 & 0,099 & 0,173 & Normal \\
Control & Post-test & 25 & 30,400 & 5,307 & 0,132 & 0,173 & Normal \\
\hline
\end{tabular}

From the results of the normality test conducted in the pre-test bound group, the calculated $\mathrm{L}$ count is 0.125 . With $\mathrm{n}=25$ and the real level of 0.05 , the $\mathrm{L}$ table count is 0.173 . It turns out that the calculated $L$ count of 0.125 is smaller than the $L$ table count of 0.173 , this means that the shooting data in the bound group pre-test is normal. From the results of the normality test performed on the post-test bound group, the calculated $\mathrm{L}$ count is 0.155 . With $\mathrm{n}=25$ and the real level of 0.05 , the $\mathrm{L}$ table count is 0.173 . It turns out that the calculated $\mathrm{L}$ count of 0.155 is smaller than the $\mathrm{L}$ table count of 0.173 , which means that the shooting data in the bound post-test group is normal.

From the results of the normality test conducted in the pre-test control group, the calculated L count was 0.099 . With $n=25$ and the real level of 0.05 , the $\mathrm{L}$ table count is 0.173 . It turns out that the 
calculated $\mathrm{L}$ count is 0.099 smaller than the $\mathrm{L}$ table count of 0.173 , this means that the shooting data in the pre-test control group is normal. From the results of the normality test conducted in the post-test control group, the calculated L count was 0.132 . With $\mathrm{n}=25$ and the real level of 0.05 , the $\mathrm{L}$ table count is 0.173 . It turns out that the calculated $\mathrm{L}$ count is 0.132 smaller than the $\mathrm{L}$ table count of 0.173 , this means that the shooting data in the post-test control group is normal.

Table 8. Summary of test results for homogeneity of the population variance

\begin{tabular}{lllllll}
\hline Group & $\mathbf{n}$ & $\begin{array}{l}\text { standard } \\
\text { deviation }\end{array}$ & Variant & $\mathbf{F}_{\text {count }}$ & $\mathbf{F}_{\text {table }}$ & Conclusion \\
\hline Bound & 25 & 4,941 & 24,417 & & \\
Control & 25 & 4,497 & 20,223 & 1,21 & 1,98 & Homogen \\
\hline
\end{tabular}

From the calculation of shooting data in the bound and control groups, the calculated $\mathrm{F}$ count is 1.21. With a numerical degree of freedom (DK) of 24 and the denominator's freedom (DK) of 24 and a real level $(\alpha)$ of 0.05 , the F table of 1.98 is obtained. It turns out that the calculated F count of 1.21 is smaller than the table F count of 1.98. This shows that the shooting data in the bound and control groups are homogeneous.

Table 9. Shooting data pre-test and post-test

\begin{tabular}{llllllll}
\hline Group & $\sum$ Pre-Test & $\sum$ Post-Test & $\begin{array}{l}\sum_{\text {different }} \\
\text { Average }\end{array}$ & $\begin{array}{l}\text { Different } \\
\text { Avunt }\end{array}$ & T $_{\text {table }}$ & Conclusion \\
\hline Bound & 770 & 951 & -181 & $-7,24$ & $-18,43$ & 2,06 & Significant \\
Control & 746 & 760 & -14 & $-0,56$ & $-1,80$ & 2,06 & Not significant \\
\hline
\end{tabular}

From the results of the t-test calculation on the bound group, the count of $t$ count is -18.43 . By using the real level $(\alpha)$ of 0.05 and the degree of freedom (DK) of 24, the t table count obtained is 2.06. It turns out that the count of $t$ count is -18.43 smaller than the count of the table of -2.06 , so there is a significant difference between the results of the shooting pre-test and the post-test. This means that there is significantly a product influence on the development of shooting training models to improve the skills of futsal players in POK UNS Futsal Achievement Development. With the product development training shooting model, empirically shown by the increase in shooting scores from pre-test to post-test of 7.24. From the results of $t$-test calculations in the control group, the count of $t$ count is -1.80 . By using the real level $(\alpha)$ of 0.05 and the degree of freedom (DK) of 24, the $t$ table count obtained is 2.06. It turns out that the count of $t$ count is -1.80 between the $t$ table counts of -2.06 and 2.06 , so there is no significant difference between the results of the pre-test and post-test shooting. This means that there is no influence on conventional models of shooting practice on futsal players. POK UNS Futsal Achievement Training. With conventional models of shooting practice, empirically shown by the increase in shooting scores from the pre-test to post-test is very small at 0.56 . 


\section{Conclusion}

From the results obtained from this study, we can know that the preparation of well-organized and structured training models can significantly improve the individual abilities of players. In addition, a neatly arranged exercise model will make it easier for trainers to make training programs in the short and long term. In making practice models, it is recommended to multiply the game elements, it aims to reduce the boredom of the players during the exercise.

Suggestions for futsal trainers are expected to be able to make more training models so that they can be used as a joint reference in improving futsal, especially in regions, schools, universities and even national circles.

\section{References}

Ardhana, W. 1987. Selected reading in educational research methods. Jakarta: PPLPTK. DG. Dikti. Ministry of Education and Culture.

Arikunto, S-2009. Research Management. Yogyakarta: Rineka Cipta.

Bompa, Tudor O. 1990. Theory and Methodology of Training The Key To Athletic Performance. Dubuque, Iowa: Kendall / Hunt.

Borg, W \& Gall, M.D 1983. Educational Research An Introduction. New York: Longman.

Brooks, George A, and Fahey Thomas P. 1984. Exercise Physiology: Human Bioenergetics and Its Applications, Ist Ed. New York: Jhon Willey \& Sons. Inc.

Budiwanto, S 2004. Basic Knowledge of Exercising Sports. Malang: Department of Sports Science, FIP UM, State University of Malang.

Degeng, S. 2002. Development Research Methodology. Malang: Ministry of National Education Education Research Center, Malang State University.

Fox, E.L., Bowers, R.W. and Fos, M.L. 1993. The Physiological Base For Exercise and Sport. Dubuque: WCB Brown Benchmark Publisher.

Hadisasmita, Y., and Syarifudin, A. 1996. Basic Coaching Sciences. Jakarta: Dep. dikbud Dirjendikti. Project for Academic Education.

Harsono. 1988. Coaching and Psychological Aspects of Coaching. Jakarta: Ministry of Education and Culture. Dirjendikti.

Halim, S. 2009. 1 Smart Day to Play Futsal. Yogyakarta: Media Presindo.

Hermans, V., and Engler, R. 2011. Futsal: Technique, Tactics, Training. UK: Meyer \& Meyer Sports Ltd.

Justinus Lhaksana. 2011. Modern Futsal Tactics and Strategies. Jakarta: Be Champion (Penebar Swadaya Group).

Lhaksana, J. 2012. Modern Futsal Tactics and Strategies. Jakarta: Be Champion. 
M. Asriady Mulyono. 2014, Buku Pintar Guide Futsal, Jakarta, Laskar Aksara.

Moleong, J. L. 2005. Qualitative Research Methodology. Bandung: PT. Teenager Rosdakarya.

Nala, Ngurah. 1988. Principles of Physical Sports Training. Denpasar: UNUD Denpasar.

Soekarman. 1985. Basic Sports for Trustees, Trainers, and Athletes. Bandung: Tarsito.

Sugiyono. 2005. Understanding Qualitative Research. Bandung: Alfabeta.

Suharno, H.P. 1986. General Coaching Science. Yogyakarta: IKIP Yogyakarta Press.

Quiet, J D. 2008. Proficient at Playing Futsal. Bandung; PT Mizan Bunaya Kretiva.

Verducci, F.M. 1980. Measurement Concepts In Physical Education. London: The C.V. Mosby Company.

White, Gary and Griffiths, David. 2013. Futsal Coaching Manual., Http: // www. Washington youth soccer. org., August 20, 2017.

Winarno, M. E. 2007. Research Methodology in Physical Education. Malang: Faculty of Education, Malang State University.

\section{Copyrights}

Copyright for this article is retained by the author(s), with first publication rights granted to the journal.

This is an open-access article distributed under the terms and conditions of the Creative Commons Attribution license (http://creativecommons.org/licenses/by/4.0/). 